\title{
EARLY ACCUMULATION OF REACTIVE OXYGEN SPECIES HAS A PIVOTAL ROLE IN NON-HOST RESISTANCE MECHANISMS IN LEGUME AND CEREAL PLANTS TO THE INCOMPATIBLE PATHOGENS \\ Hafez, Y. M. \\ Dept. of Agricultural Botany (Plant Pathology Branch), Faculty of Agriculture, Kafr-El-Sheikh University, 33516 Kafr-El-Sheikh, Egypt \\ Email: hafezyasser@gmail.com, Tel.: 00201063700994, \\ Fax: 0020473102930
}

\begin{abstract}
Most of plants under normal conditions are resistant to most of the incompatible pathogens (viral, fungal and bacterial infections). This is called "non-host resistance (NHR) phenomenon". It is very important to answer the question, why nonhost plants are resistant? As a result of inoculation of legume (pea and soybean) and cereal (barley and wheat) plants with compatible and incompatible pathogens, strong resistance symptoms were observed in the non-host/incompatible pathogen combinations as compared with host/compatible pathogen combinations which showed severe infection (susceptibility). Levels of reactive oxygen species (ROS) mainly hydrogen peroxide $\left(\mathrm{H}_{2} \mathrm{O}_{2}\right)$ and superoxide $\left(\mathrm{O}_{2}{ }^{-}\right)$were significantly increased early $6,12,24$ and 36 hours after inoculation (hai) in the non-host plants as compared with host plants. Interestingly enough that the activities of the antioxidant enzymes such as catalase (CAT), dehydroascorbate reductase (DHAR) and peroxidase (POX) were not significantly increased at the same early time 6 - 36 hai in the non-host plants. However, these enzymes were significantly increased later on 48, 72 and 96 dai in the non-host plants as compared with host plants. It seems that early accumulation of $\mathrm{H}_{2} \mathrm{O}_{2}$ and $\mathrm{O}_{2}{ }^{-}$could have a dual roles, first role is inhibiting or killing the pathogens early in the non-host plants, second immunization of the non-host plants by stimulating the activities of the antioxidant enzymes later on which thereby, neutralize the harmful effect of ROS and consequently suppressing disease symptoms. The author recommends giving more attention to these new mechanisms of non-host resistance particularly in relation to ROS levels and antioxidant activities which are very important for plant breeders and useful for finding alternative control strategies as well.
\end{abstract}

Keywords: Antioxidants, ROS, Non-host resistance, legumes, cereals

\section{INTRODUCTION}

Non-host resistance (NHR) is a resistance exhibited by an entire plant species to all genetic variants of a non-adapted pathogen species. NHR refers to plant species immunity against the majority of microbial pathogens and represents the most healthy and strong form of plant resistance in nature (Lipka et al., 2010; Yulin et al., 2012). NHR phenomenon explains why most of plants are immune to the enormous majority of potential pathogens and normally healthy. Mechanisms supporting NHR remain relatively unknown compared with the well-studied host resistance mediated by the products of plant resistance $(R)$ genes, which establish pathogen race- or plant cultivarspecific resistance (Dangl and Jones 2001; Schulze-Lefert and Bieri 2005). 
NHR plants to pathogens mainly fungal, bacterial and viral infections can be defined as an innate non-specific resistance which is effective against all known isolates of several species of the pathogens (Thordal-Christensen, 2003, Király et al., 2007). This NHR resistance is a durable and very effective type of plant immunity (Heath, 2000). On the other hand, appropriate pathogens escape defense reactions of the host by avoiding recognition or suppressing resistance of non-host or host but resistant plants (SchulzeLefert and Panstruga, 2003). Researchers conducted some experiments in relation to genetics of non-host type of resistance. However, only a few biochemical results are available as regards the formation of host cell wall appositions (papillae), local accumulation of autofluorogens and reactive oxygen species (ROS), such as hydrogen peroxide $\left(\mathrm{H}_{2} \mathrm{O}_{2}\right)$ (Carver et al., 1992; Hückelhoven et al., 2001; Trujillo et al., 2004).

Pea (Pisum sativum L.) is one of the most important legume vegetable crops grown in Egypt and many other countries all over the world. It has many nutritional values such as high content of protein, carbohydrates, phosphorus, iron, calcium and vitamins A and B (Watt and Merrill, 1963). Soybean (Glycine max L.) is one of the world's most important sources of oil and protein. It has the highest protein content among leguminous crops (Abdel-Monaim et al., 2011). Barley (Hordeum vulgare L.) ranks the fourth among the major cereal grians in terms of World and Egyptian production after maize, wheat and rice crops (Hafez et al., 2014). Wheat (Triticum aestivum L.) is one of the most important cereal crops in the world for both human food and animal feed (Chen et al., 2003; Abdelaal et al., 2014). These important plants can be seriously damaged by Botrytis cinerea, Alternaria solani, Blumeria graminis f.sp. hordei (Bgh) and Blumeria graminis f.sp. tritici $(B g t)$. Due to the massive and economic damages of these host/pathogen interactions, research into the functional and characterization of new resistance mechanisms are needed. According to our knowledge, not too much experimental results have been achieved which would explain the question: what is arresting or killing the pathogens in the non-host resistant plants? However, some promising and preliminary results were obtained which indicated that ROS have a pivotal role in the arrest of pathogens in non-host plants (Hafez et al., 2007, Hafez et al., 2011). However, till now little is known about the nature of effective defense mechanisms in pea, soybean, barley and wheat plants to incompatible pathogens, especially pathogens with economic and biological importance.

The aim of this research study, was to characterize the mode of action of the non-host resistance mechanisms in pea, soybean, barley and wheat to the Papya ring spot virus (PRSV), B. cinerea, B. graminis f.sp. riticit and $B$. graminis f.sp. hordei respectively at the morphological, histological and biochemical levels which thereby, very useful for plant breeders and sustainable crop protection.

\section{MATERIALS AND METHODS}

\section{1. Plant materials}

Pea (Pisum sativum L.) cultivar (cv.) Little Marvel and soybean (Glycine max L.) Cv. Giza 111 seeds were obtained from Food Legumes Research 
Section, Sakha, Kafr El-Sheikh, Field Crops Research Institute (FCRI), Agricultural Research Station (ARC), Egypt. Barley (Hordeum vulgare L.) cv. Giza 123 seeds obtained from Dept. of Barley, FCRI, ARC, Egypt. Wheat (Triticum sativum L.) Cv. Sakha 61 was obtained from Wheat Pathology Department, Sakha, Kafr El-Sheikh, ARC, Egypt. Seeds were sown in a 12$\mathrm{cm}$ plastic pots containing soil mixed with peat moss $(1: 1)$ and grown in the greenhouse. Temperature was $18-23{ }^{\circ} \mathrm{C}$, with 16 hours photoperiod per day using supplemental light with a light intensity of $160 \mu \mathrm{E} \mathrm{m} \mathrm{m}^{-2}$ and relative humidity $75-80 \%$. These experiments were conducted in the laboratories, green houses and growth chambers of Botany Department, Faculty of Agriculture, Kafr-Elsheikh University, Egypt as well as Plant Pathophysiology Department, Plant Protection Institute, Hungarian Academy of Sciences, Budapest, Hungary during the years 2012 -2014.

\section{2. Plant pathogens}

The Papaya ringspot virus (PRSV) Egyptian isolate was obtained from Plant Pathology and Biotechnology Laboratory, Faculty of Agriculture, KafrElsheikh University, Egypt. PRSV was maintained on the host susceptible squash (Cucurbita pepo). For mechanical virus inoculation, viral-infected leaves were homogenized in tap water. Carborundum was used as an abrasive for virus and mock inoculations (Hafez, 2009).

Botrytis cinerea Pers., Bc-1 and Alternaria solani isolates were kindly supplied by Prof. László Vajna, Plant Protection Institute, Hungarian Academy of Sciences, Hungary. These pathogens were maintained on potato dextrose agar medium (PDA) under continuous fluorescent light. For inoculation, agar discs $5 \mathrm{~mm}$ in diameter were cut from 7-day-old cultures of the fungus Botrytis cinerea and 15-days old culture of the fungus Alternaria solani then, placed on the surface of pea and soybean leaves, respectively. Leaves were cut and put on wet filter paper in a Petri dish and held at $20^{\circ} \mathrm{C}$ in continuous light for at least 3 days for pea and 2-5 days for soybean (Hafez et al., 2012).

Barley powdery mildew (Blumeria graminis f. sp. hordei) and wheat powdery mildew (Blumeria graminis f. sp. tritici) Egyptian specimens were maintained under greenhouse conditions and were used for all inoculation experiments. Powdery mildew inocula were dispersed in the greenhouse atmosphere by placing plants of barley and wheat bearing sporulating colonies of both pathogens beneath ventilation fans of the greenhouse (Hafez and Kiraly, 2003).

\subsection{Disease severity assessments}

Disease severity percentage (\%) of pea inoculated with $B$. cinerea (host) and PRSV (non-host) as wel as soybean inoculated with $A$. solani (host) and B. cinerea (non-host) were measured as lesion diameter $\left(\mathrm{cm}^{2}\right)$ according to Hafez et al., 2004. However, the disease severity percentage (\%) of barley inoculated with barely powdery mildew (host) and inoculated with wheat powdery mildew (non-host) as well as wheat inoculated with wheat powdery mildew (host) and inoculated with barley powdery mildew (nohost) were determined as follows: Ten plants of each replicate were scored visually for percentage of leaf area covered by powdery mildew on a 0 
(resistant) to 10 (susceptible) scale three times 3, 6 and 9 days after inoculation (dai) in each experiment. For analysis, disease scores were converted using the modified logarithmic scale of Horsfall-Barrett (Horsfall and Cowling, 1978) and Hafez et al., 2014. The scale was $0=0 \%, 1=0-3$ $\%, 2=+3-6 \%, 3=+6-12 \%, 4=+12-25 \%, 5=+25-50 \%, 6=+50-75 \%, 7$ $=+75-88 \%, 8=+88-94 \%, 9=+94-97 \%$ and $10=+97-100 \%$. Disease severity index (DSI) was calculated according to Kim et al. (2000) using the following formula:

$$
\text { DSI }=\frac{\sum \text { Ratings of each plant }}{10 \times \text { Number of plants rated }} \times 100
$$

Histochemical staining for $\mathrm{O}_{2} \cdot-$ production in leaf tissue was based on the ability of $\mathrm{O}_{2}{ }^{--}$to reduce nitro blue tetrazolium (NBT). $\mathrm{O}_{2}{ }^{--}$was visualised as a purple coloration of NBT. Leaf discs $(2 \mathrm{~cm})$ of pea and soybean plants as well as hall barley and wheat leaves were vacuum infiltrated or injected (Hagborg, 1970) with $10 \mathrm{mM}$ potassium phosphate buffer ( $\mathrm{pH} 7.8$ ) containing $0.1 \mathrm{w} / \mathrm{v} \%$ NBT (Sigma-Aldrich, Germany) according to Ádám et al., (1989). NBT-treated samples were incubated under daylight for $20 \mathrm{~min}$ and subsequently cleared in $0.15 \%$ trichloroacetic acid (wt/vol) in ethanol: chloroform 4:1 (vol $/ \mathrm{vol})$. The solution was exchanged once during the next $48 \mathrm{~h}$ of incubation (Hückelhoven et al., 1999). Subsequently, leaf discs and leaves were stored in $50 \%$ glycerol for evaluation.

For histochemical analysis of hydrogen peroxide $\left(\mathrm{H}_{2} \mathrm{O}_{2}\right)$, leaf discs and hall leaves were infiltrated with $0.1 \% 3$, 3-diaminobenzidine (DAB) in $10 \mathrm{mM}$ Tris buffer ( $\mathrm{pH}$ 7.8). Samples were incubated under daylight for two hours after the vacuum infiltration. Following staining, leaves were cleared as described above and the intensity of brown color was estimated (Hückelhoven et al., 1999). Levels of $\mathrm{O}_{2}{ }^{-}$and $\mathrm{H}_{2} \mathrm{O}_{2}$ were estimated $6,12,24,36$, and 48 hours after inoculation. These tests were repeated five times during six independent experiments.

\section{5. Biochemical assays of antioxidant enzymes}

The tested antioxidant enzyme activities were measured on 5 weeksold pea and soybean plants as well as 2 weeks-old barley and wheat plants. For enzyme assays in plants, $0.5 \mathrm{~g}$ leaf material was homogenized at $0-4^{\circ} \mathrm{C}$

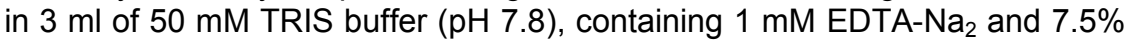
polyvinylpyrrolidone $1,2,3$ and 4 days after inoculation. The homogenates were centrifuged $\left(12,000 \mathrm{rpm}, 20 \mathrm{~min}, 4^{\circ} \mathrm{C}\right)$, and the total soluble enzyme activities were measured spectrophotometrically in the supernatant (Hafez, 2010, Hafez et al., 2014). All measurements were carried out at $25^{\circ} \mathrm{C}$, using the model UV-160A spectrophotometer (Shimadzu, Japan).

Activity of catalase (CAT) was determined spectrophotometrically according to Aebi (1984). Decomposition of $\mathrm{H}_{2} \mathrm{O}_{2}$ by catalase results in the decrease of the ultraviolet absorption of hydrogen peroxide at $240 \mathrm{~nm}$. Enzyme activity can be calculated from this decrease. The reaction mixture contained, in a final volume of $2.15 \mathrm{ml}, 2 \mathrm{ml} 0.1 \mathrm{M} \mathrm{Na}$-phosphate buffer $(\mathrm{pH}$ 6.5), $100 \mu \mathrm{l}$ hydrogen peroxide and $50 \mu \mathrm{l}$ leaf extract supernatant. The 
solution is mixed, and then the absorption change is registered for $3 \mathrm{~min}$ at $240 \mathrm{~nm}$ using a quartz cuvette.

Activity of dehydroascorbate reductase (DHAR) was determined spectrophotometrically according to Asada (1984). The reaction mixture contained, in a final volume of $2.3 \mathrm{ml}, 50 \mathrm{mM}$ sodium phosphate buffer $(\mathrm{pH}$ $6.5), 0.5 \mathrm{mM}$ dehydroascorbate (DHA), $1.0 \mathrm{mM}$ reduced glutathione (GSH), $0.1 \mathrm{mM}$ EDTA and $0.1 \mathrm{ml}$ supernatant. The assay was carried out in quartz cuvettes following the increase in absorbance at $265 \mathrm{~nm}$ due to the formation of ascorbate with extinction coefficient $14 \mathrm{mM}^{-1} \mathrm{~cm}^{-1}$ (Klapheck et al., 1990). The reaction rate was corrected for the non-enzymatic reduction of dehydroascorbate by GSH.

Activity of peroxidase (POX) was directly determined of the crude enzyme extract according to a typical procedure proposed by Hammerschmidt et al., (1982). Changes in absorbance at $470 \mathrm{~nm}$ were recorded every $30 \mathrm{sec}$ intervals for $3 \mathrm{~min}$. Enzyme activity was expressed as increase in absorbance $\mathrm{min}^{-1} \mathrm{~g}^{-1}$ fresh weight.

\section{6. Statistical analysis}

Six experiments were conducted in a completely randomized design with five replicates for each treatment. Data represent the mean $\pm S D$. Student's t-test was used to determine whether significant difference $(P<0.05)$ existed between mean values according to O'Mahony (1986).

\section{RESULTS AND DISCUSSION}

\section{Disease severity and disease symptoms of host and non-host/pathogen combinations}

In the "non-host" plants pea, soybean, barley and wheat showed resistance against Papaya ringspot virus, $B$. cinerea, Blumeria graminis $\mathrm{f}$. $\mathrm{sp}$. tritici and Blumeria graminis f. sp. hordei, respectively compared to the "host" plants pea, soybean, barley and wheat inoculated with Botrytis cinerea, Alternaria solani, Blumeria graminis f. sp. hordei and Blumeria graminis f. $\mathrm{sp}$. tritici, respectively showed strong susceptibility.

Disease severity percentage was significantly severe strongly in all the host/pathogen combinations as compared to the non-host/pathogen combinations (Fig. 1 and Table 1).

Disease symptoms were also significantly appeared and visible in the host/pathogen combinations compared to the non-host which no symptoms appeared (Fig. 2). Similar results have been obtained by Fabro et al. (2011) in which found that in the "non-host" plant Brassica rapa (turnip) which was more effectors of Hyaloperonospora arabidopsidis are recognized than in Arabidopsis thaliana which is a "host" of this oomycete pathogen. This could be a possible cause of the inability of $H$. arabidopsidis to grow in turnip. In other words, the host plant cannot recognize a subset of effectors of its own pathogen which are recognized, and therefore induce an immune reaction in the non-host. However, it is still an unanswered question, how this immune reaction can inhibit pathogens in non-host plants? (Kiraly et al., 2013). 


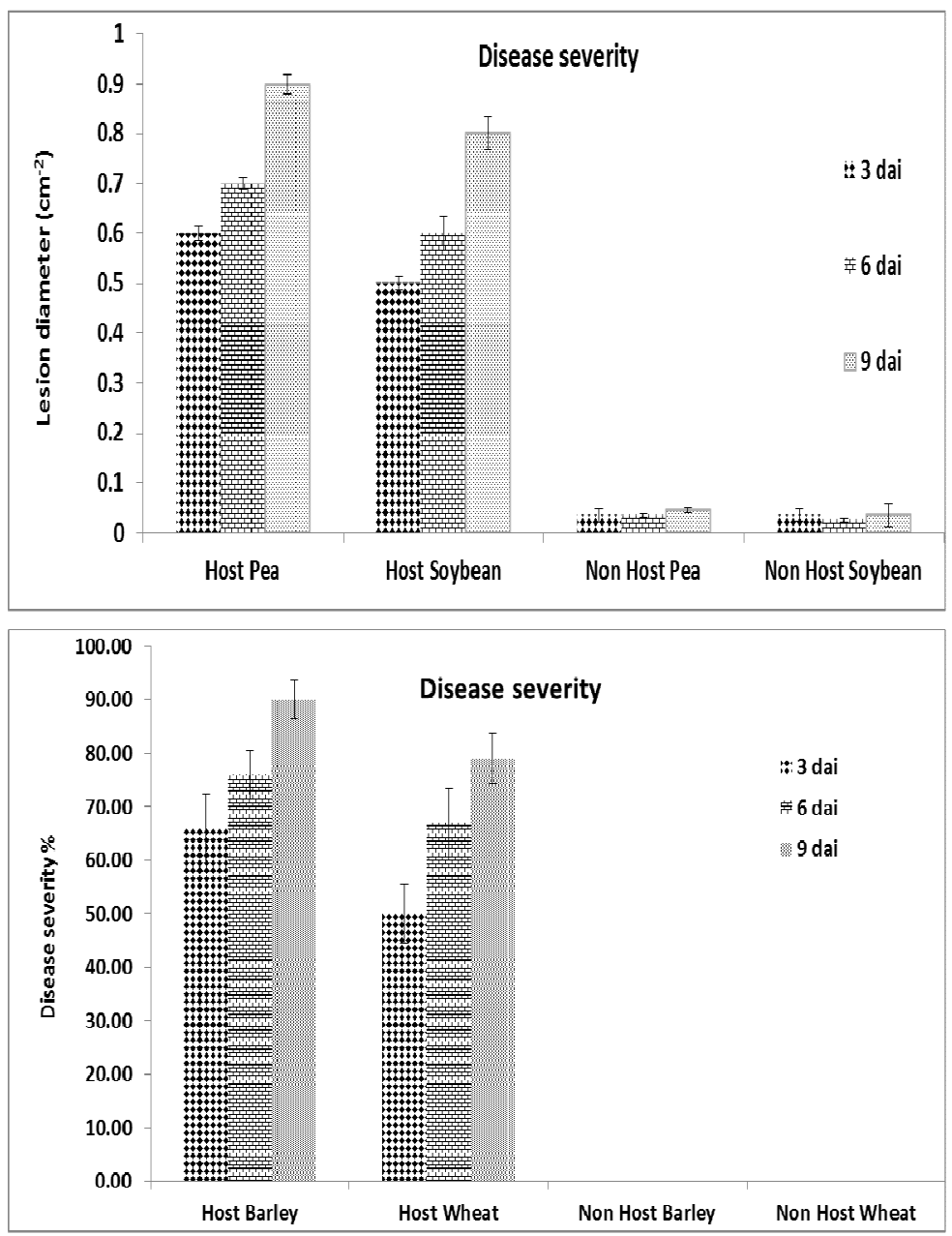

Fig. (1): Disease severity percentage (\%) of host and non-host/pathogen combinations 3, 6 and 9 days after inoculation (dai) of pea, soybean, barley and wheat plants. Host Pea: leaves inoculated with Botrytis cinerea. Host soybean: leaves inoculated with Alternaria solani. Non Host Pea: leaves inoculated with Papaya ringspot virus. Non Host soybean: leaves inoculated with $B$. cinerea. Host Barley: leaves inoculated with Blumeria graminis f. sp. hordei (Bgh). Non Host Barley: leaves inoculated with Blumeria graminis f. sp. Tritici (Bgt). Host Wheat: leaves inoculated with Bgt.Non Host Wheat: leaves inoculated with Bgh 
Table 1. Reaction of host and non-host/pathogen combinations

\begin{tabular}{|l|c|c|c|c|}
\hline Plants & Host & Results & Non-host & Results \\
\hline Pea & Botrytis cinerea & $\mathrm{S}$ & Papaya ringspot virus & $\mathrm{R}$ \\
\hline Soybean & Alternaria solani & $\mathrm{S}$ & Botrytis cinerea & $\mathrm{R}$ \\
\hline Barley & $\begin{array}{c}\text { Blumeria graminis f. sp. } \\
\text { hordei }\end{array}$ & $\mathrm{S}$ & $\begin{array}{c}\text { Blumeria graminis f. sp. } \\
\text { tritici }\end{array}$ & $\mathrm{R}$ \\
\hline Wheat & $\begin{array}{c}\text { Blumeria graminis f. sp. } \\
\text { tritici }\end{array}$ & $\mathrm{S}$ & $\begin{array}{c}\text { Blumeria graminis f. sp. } \\
\text { hordei }\end{array}$ & $\mathrm{R}$ \\
\hline
\end{tabular}

$\mathrm{S}=$ susceptible $\quad \mathrm{R}=$ resistant

Levels of reactive oxygen species in host and non-host/pathogen combinations

Purple discoloration of superoxide $\left(\mathrm{O}_{2}{ }^{-}\right)$and brown discoloration of hydrogen peroxide $\left(\mathrm{H}_{2} \mathrm{O}_{2}\right)$ reflect the intensivity of ROS levels in the leaves which cleared from chlorophyll (Fig. 2). Levels of ROS mainly $\mathrm{O}_{2}{ }^{--}$and $\mathrm{H}_{2} \mathrm{O}_{2}$ significantly accumulated early 6, 12, 24 and 36 hours after inoculation (hai) in all non-host/pathogen combinations in pea, soybean, barley and wheat plants (Figs. 3, 4 and 5). It is known that there is a definite correlation between ROS accumulation and inhibition of plant pathogens in resistant (immune) plants, the cause-and-effect relationship between these two events (i.e. ROS accumulation and disease resistance) is not entirely clear so far (Kiraly et al., 2103). In these results, the author has observed that in a series of plant/pathogen interactions, the "non-host" type of resistance is associated with an early activation of $\mathrm{O}_{2}$ and $\mathrm{H}_{2} \mathrm{O}_{2}$. This accumulation in resistant nonhost plants, could inhibit or kill pathogens early after inoculation (Figs. 3, 4 and 5). These results indicated that the "non-host" type of resistance recognized in pea inoculated with $P R S V$ virus, soybean inoculated with $B$. cinerea, barely inoculated with wheat powdery mildew (Blumeria graminis $\mathrm{f}$. $\mathrm{sp}$. tritici) and wheat inoculated with barley powdery mildew (Blumeria graminis f. sp. horei). As is seen pea, soybean, barley and wheat are incompatible (non-hosts) for these pathogenic fungi which resulted in resistance with inhibition of the pathogen and suppressed symptoms, but are compatible (hosts) with another pathogens which resulted in susceptibility with development of typical disease symptoms and unarrested growth of the pathogen (Table, 1). Accordingly, the cause of symptomless non-host resistance could be attributed to the early inhibition or killing of infectious agents by ROS. However, in host plants exhibiting susceptibility, pathogen growth is uninhibited and consequently disease symptoms are produced possibly because there is no ROS accumulation after infection which could be due to elevated antioxidant capacity of the host early after inoculation (ElZahaby et al., 1995; Harrach et al., 2008). 
Activities of antioxidant enzymes in host and non-host/pathogen combinations

Activities of antioxidant enzymes such as catalase (CAT), dehydroascorbate reductase (DHAR) and peroxidase (POX) were not changed or even increased early 6, 12, 24 and 36 hours after inoculation (hai) in all non-host/pathogen combinations in pea, soybean, barley and wheat plants, however, these enzymes were increased significantly a little bit later at 48, 72 and 96 hai (Figs. 6 and 7).

Pea

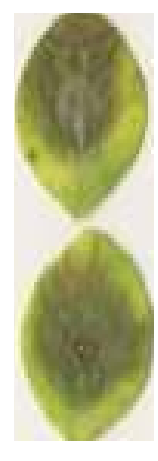

Host
Soybean

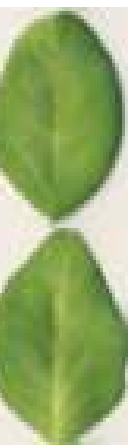

Non-Host

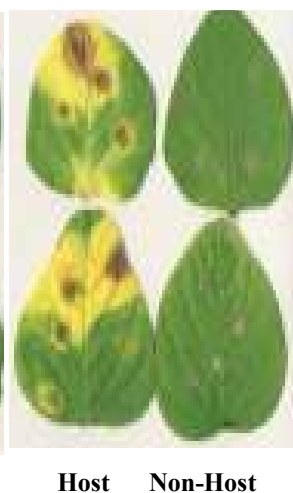

Barley

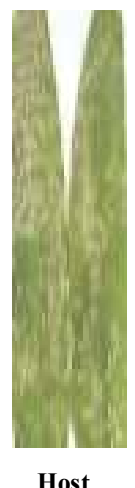

Wheat

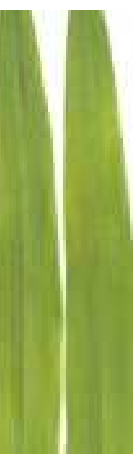

Non-Host

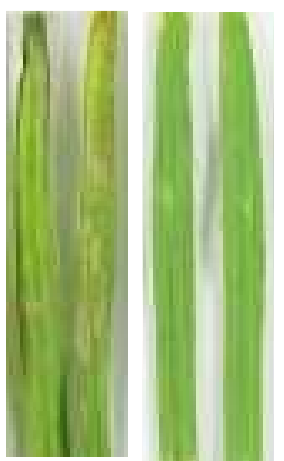

Host Non-Host

Fig. (2): Disease symptoms of host and non-host/pathogen combinations 4 days after inoculation (dai) in pea and soybean as well as 2 dai in barley and wheat plants. Host Pea: leaves inoculated with Botrytis cinerea. Host soybean: leaves inoculated with Alternaria solani. Non Host Pea: leaves inoculated with Papaya ringspot virus. Non Host soybean: leaves inoculated with $B$. cinerea. Host Barley: leaves inoculated with Blumeria graminis f. sp. hordei (Bgh). Non Host Barley: leaves inoculated with Blumeria graminis f. sp. Tritici (Bgt). Host Wheat: leaves inoculated with Bgt.Non Host Wheat: leaves inoculated with Bgh 

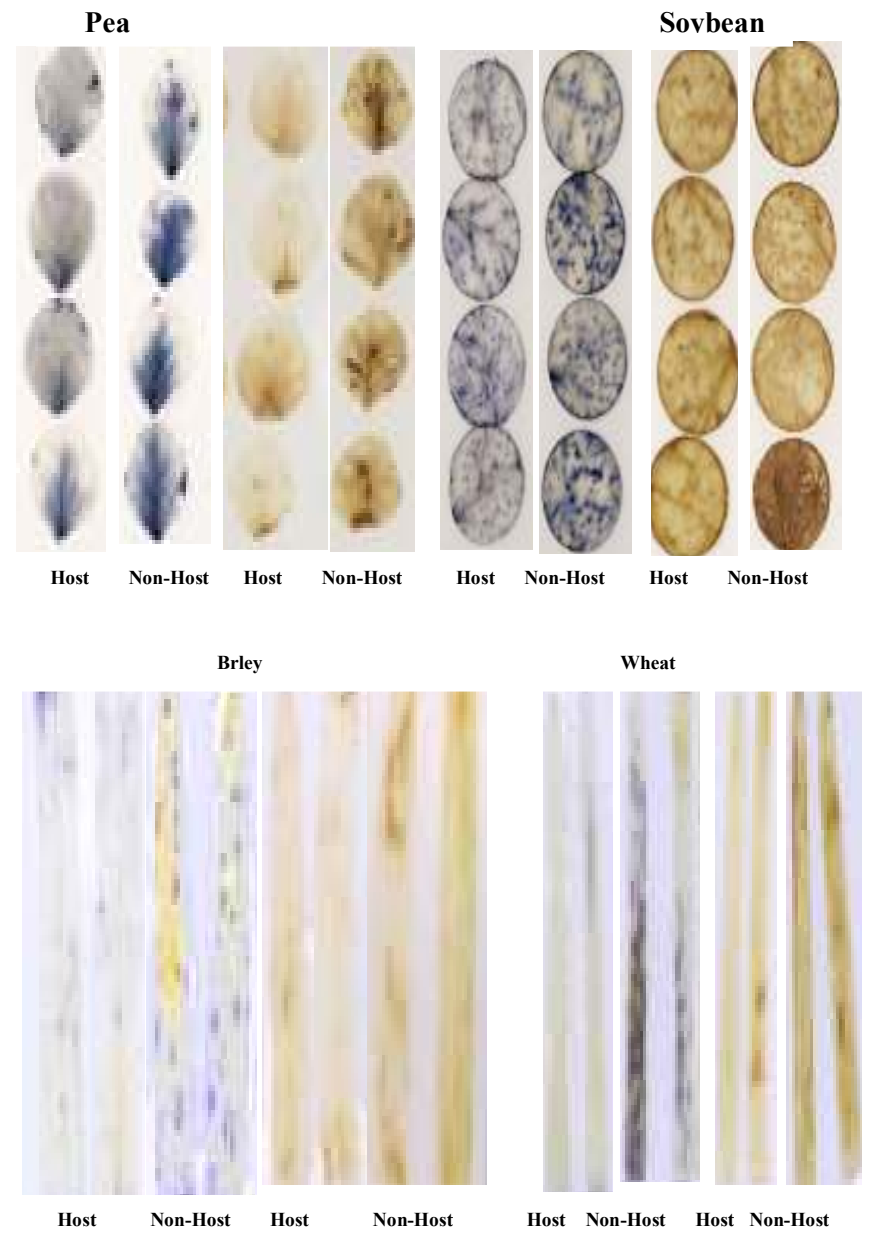

Fig. (3): Purple discoloration of superoxide $\left(\mathrm{O}_{2}\right)$ and brown discoloration of hydrogen peroxide $\left(\mathrm{H}_{2} \mathrm{O}_{2}\right)$ of host and non-host/pathogen combinations 12 hours after inoculation (dai) in pea and soybean as well as 6 hai in barley and wheat plants. Host Pea: leaves inoculated with Botrytis cinerea. Host soybean: leaves inoculated with Alternaria solani. Non Host Pea: leaves inoculated with Papaya ringspot virus. Non Host soybean: leaves inoculated with $B$. cinerea. Host Barley: leaves inoculated with Blumeria graminis $f$. sp. hordei (Bgh). Non Host Barley: leaves inoculated with Blumeria graminis f. sp. Tritici (Bgt). Host Wheat: leaves inoculated with Bgt.Non Host Wheat: leaves inoculated with Bgh

One can say that in these non-host resistant pea, soybean, barley and wheat plants the early accumulation of $\mathrm{O}_{2}{ }^{-}$and $\mathrm{H}_{2} \mathrm{O}_{2}$ not only inhibit or kill the 
incompatible pathogens 6-36 hai but also stimulate the activities of antioxidants CAT, DHAR and POX alter on 24-96 hai.

Our results are supported by our previous results in which pointed out that under natural conditions the up-regulation of antioxidant defense systems seems to be a general response to oxidative stress (Hafez et al., 2012).

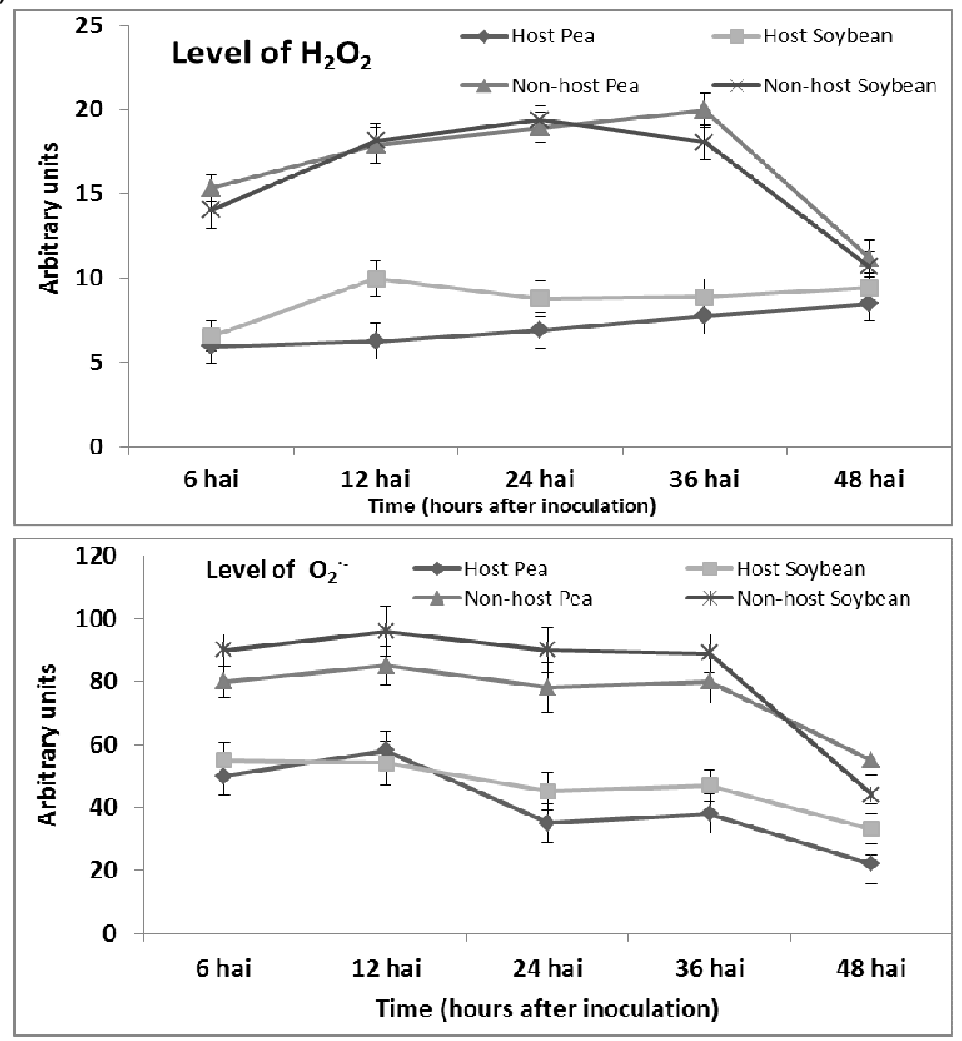

Fig. (4): Levels of hydrogen peroxide $\left(\mathrm{H}_{2} \mathrm{O}_{2}\right)$ and superoxide $\left(\mathrm{O}_{2}\right)$ of host and non-host/pathogen combinations $6,12,24,36$ and 48 hours after inoculation (hai) in pea and soybean plants. Host Pea: leaves inoculated with Botrytis cinerea. Host soybean: leaves inoculated with Alternaria solani. Non Host Pea: leaves inoculated with Papaya ringspot virus. Non Host soybean: leaves inoculated with $B$. cinerea. Host Barley: leaves inoculated with Blumeria graminis f. sp. hordei (Bgh). Non Host Barley: leaves inoculated with Blumeria graminis f. sp. Tritici (Bgt). Host Wheat: leaves inoculated with Bgt.Non Host Wheat: leaves inoculated with Bgh

The early accumulation of ROS in the non-host resistant plants upregulate the antioxidants go along with the results which proved that $\mathrm{H}_{2} \mathrm{O}_{2}$ as 
one of the most important reactive oxygen species associated with oxidative stress, can up-regulate antioxidant systems even at very low concentrations against abiotic stress (Gechev et al., 2002) and also immunize plants, therefore, induces resistance to symptom development by suppressing pathogen-induced host cell and tissue necroses but not pathogen multiplication, while enhancing activities of at least three antioxidant enzymes such as catalase, guaiacol peroxidase and ascorbate peroxidase ( Hafez et al., 2012).
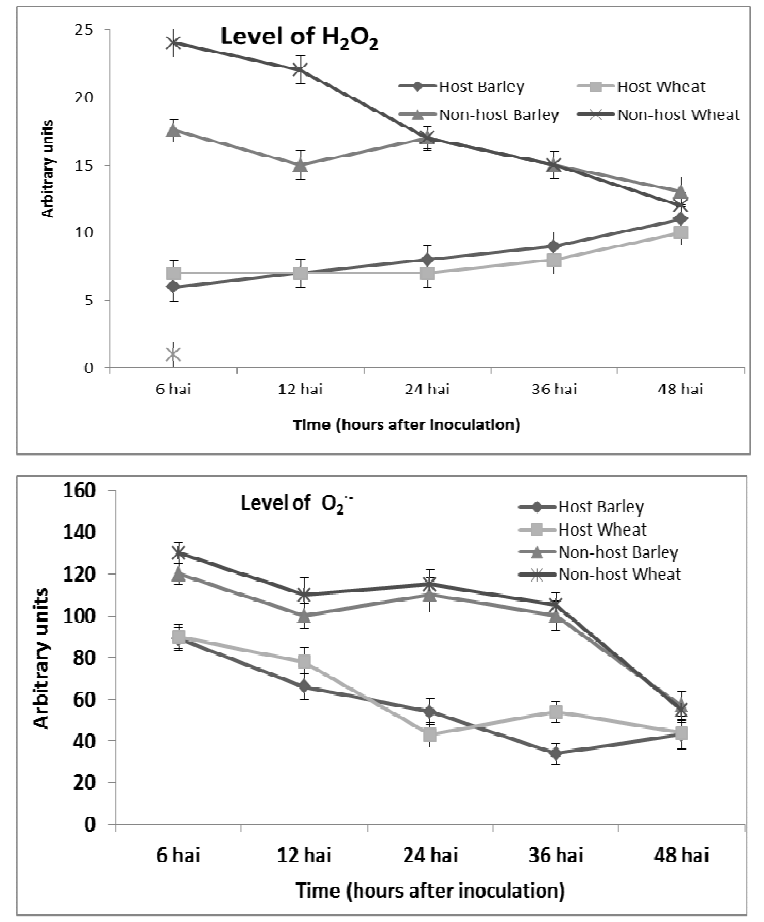

Fig. (5): Levels of hydrogen peroxide $\left(\mathrm{H}_{2} \mathrm{O}_{2}\right)$ and superoxide $\left(\mathrm{O}_{2}{ }^{\left.-{ }^{-}\right)}\right.$of host and non-host/pathogen combinations 6, 12, 24, 36 and 48 hours after inoculation (hai) in barley and wheat plants. Host Pea: leaves inoculated with Botrytis cinerea. Host soybean: leaves inoculated with Alternaria solani. Non Host Pea: leaves inoculated with Papaya ringspot virus. Non Host soybean: leaves inoculated with $B$. cinerea. Host Barley: leaves inoculated with Blumeria graminis f. sp. hordei (Bgh). Non Host Barley: leaves inoculated with Blumeria graminis f. sp. Tritici (Bgt). Host Wheat: leaves inoculated with Bgt.Non Host Wheat: leaves inoculated with Bgh 
Hafez, Y. M.
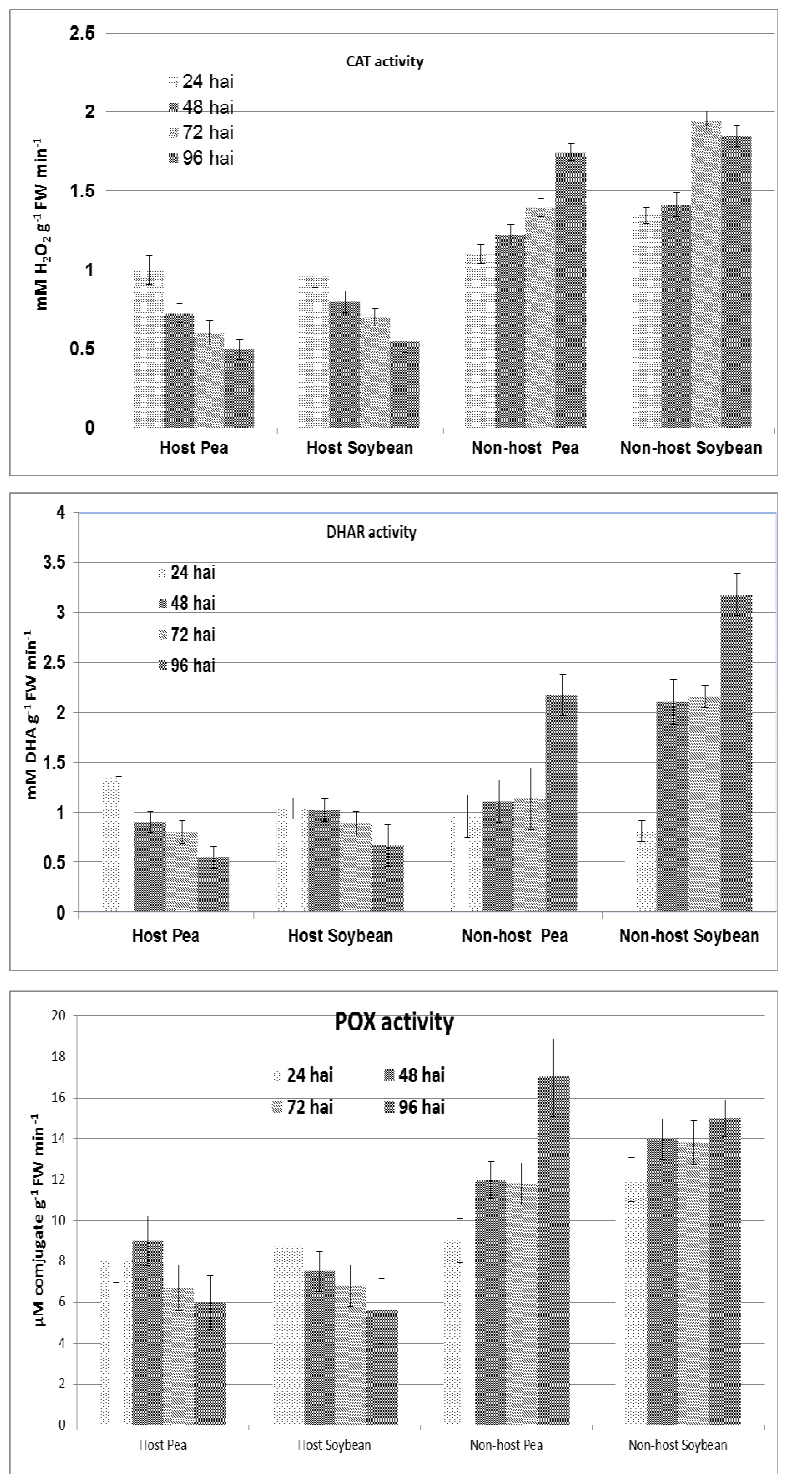

Fig. (6): Activities of antioxidant enzymes catalase (CAT), dehydroascorbate reductase (DHAR) and peroxidase (POX) in host and non-host/pathogen combinations 24 48, 72 and 96 hours after inoculation (hai) in pea and soybean plants. Host Pea: leaves inoculated with Botrytis cinerea. Host soybean: leaves inoculated with Alternaria solani. Non Host Pea: leaves inoculated with Papaya ringspot virus. Non Host soybean: leaves inoculated with $B$. cinerea. Host Barley: leaves inoculated with Blumeria graminis f. sp. hordei (Bgh). Non Host Barley: leaves inoculated with Blumeria graminis f. sp. Tritici (Bgt). Host Wheat: leaves inoculated with Bgt.Non Host Wheat: leaves inoculated with Bgh 

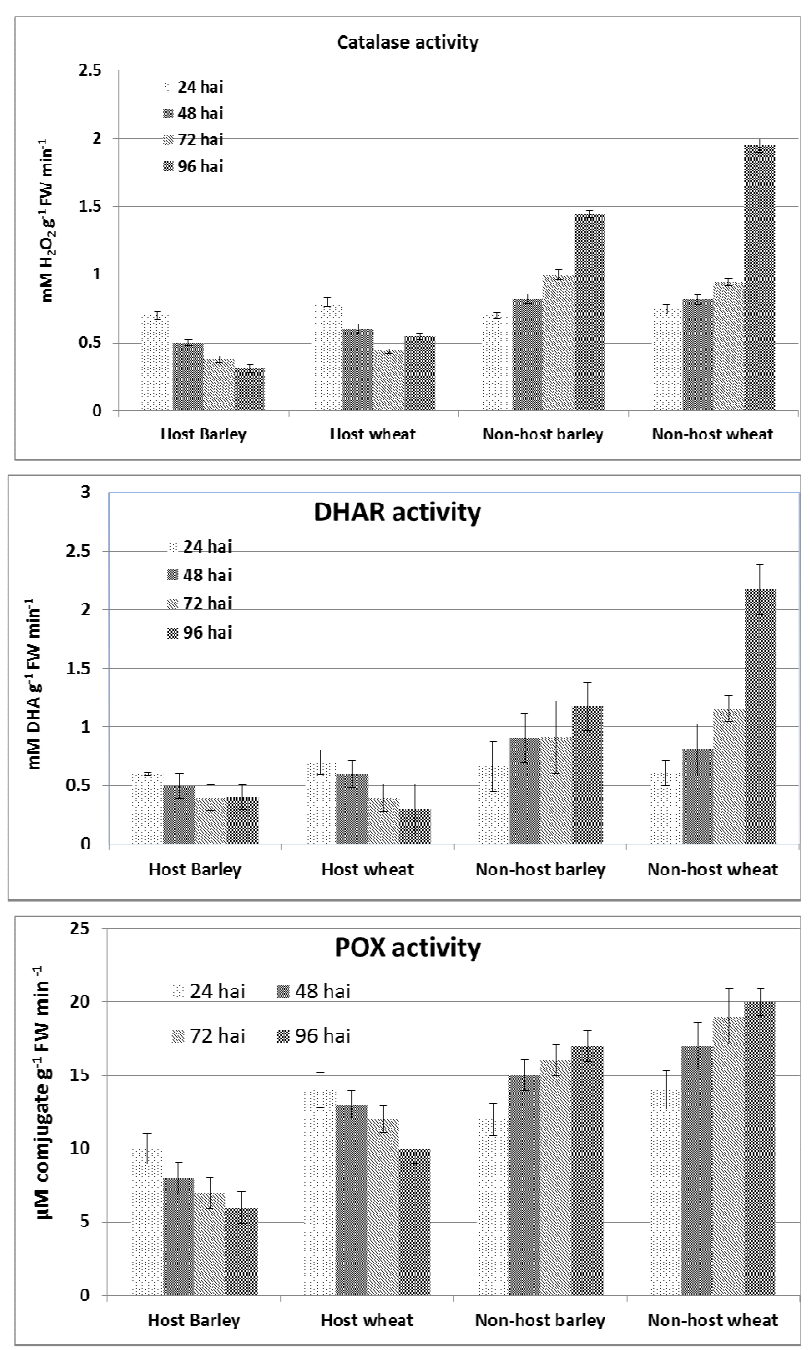

Fig. (7): Activities of antioxidant enzymes catalase (CAT), dehydroascorbate reductase (DHAR) and peroxidase (POX) in host and nonhost/pathogen combinations 24 48, 72 and 96 hours after inoculation (hai) in barley and wheat plants. Host Pea: leaves inoculated with Botrytis cinerea. Host soybean: leaves inoculated with Alternaria solani. Non Host Pea: leaves inoculated with Papaya ringspot virus. Non Host soybean: leaves inoculated with $B$. cinerea. Host Barley: leaves inoculated with Blumeria graminis f. sp. hordei (Bgh). Non Host Barley: leaves inoculated with Blumeria graminis f. sp. Tritici (Bgt). Host Wheat: leaves inoculated with Bgt.Non Host Wheat: leaves inoculated with Bgh 
It was pointed out that often the only evidence that oxidative stress has occurred in vivo may be it is the cause of up-regulation of antioxidant defense systems (Halliwell and Gutteridge, 1999). The high activities of enzymatic and nonenzymatic antioxidants neutralized the harmful effects of ROS (oxidative stress). Particularly, $\mathrm{H}_{2} \mathrm{O}_{2}$ seems to play a dual role by eliciting localized death of plant and pathogen cells and as a diffusible signal for the induction of antioxidant and pathogenesis-related genes in adjacent plant tissues (Levine et al., 1994; Wu et al., 1997; Hafez et al., 2012).

It worth mentioning that the author use for this research four model important plants, two from legumes (pea and soybean) and two from cereals (barley and wheat) which support his new findings. The author was able to characterize new histochemical and biochemical mechanisms which explain partially the question: why non-host plant is resistant to the incompatible pathogen? One can answer this puzzling question by saying that, as a result of inoculation of non-host plant with incompatible pathogens, ROS mainly superoxide and hydrogen peroxide accumulated early which may be killing or inhibiting the pathogens in these non-host plants. This early accumulation of ROS stimulated the antioxidant enzymes activities later on which thereby could immunize plants by suppressing disease symptoms and neutralize the harmful effect of ROS against these incompatible pathogens.

In summary, the author recommends the researchers and plant breeders to give more attention to these interesting new results to find new strategies for future integrated pest management practices and sustainable crop protection.

\section{Aknowledgement}

This research was conducted and funded by the Plant Pathology and Biotechnology Lab., (under accreditation of ISO/17025), EPCRS Excellence Centre, Dept. of Agric. Botany, Fac. of Agric., Kafrelsheikh University, KafrElsheikh, Egypt and Plant Protection Institute, Hungarian Academy of sciences, Hungary during the years 2012-2014. The EPCRS Excellence Centre Project is funded by Management Supporting Excellence (MSE), Development Projects Management Unit, Ministry of Higher Education, Egypt.

\section{REFERENCES}

Abdelaal, Kh.A.A., Y.M. Hafez, Adel Samar M., W.A. Youseef and M.M. Badr. 2014. Biochemical, histological and molecular changes in some Egyptian wheat varieties infected with stripe rust (Puccinia striiformis f.sp. tritici). Egyptian J. Biol. Pest Cont., 24 (2): 421-429

Abdel-Monaim M.F., M.E. Ismail and K.M. Morsy. 2011. Induction of systematic resistance in soybean plants against Fusarium wilt disease by seed treatment with benzothiadiazole and humic acid. Not. Sci. Biol., 3(2):8089.

Ádám A., T. Farkas, G. Somlyai , M. Hevesi and Z. Király. 1989. Consequence of $\mathrm{O}_{2}{ }^{--}$generation during a bacterially induced hypersensitive reaction in tobacco: deterioration of membrane lipids. Physiol. Molec. Plant Pathol., 34: 13-26.

Aebi, H. 1984. Catalase in vitro. Methods Enzymol., 105: 121-126. 
Asada, K. 1984. Chloroplast formation of reactive oxigen and its scavenging. In: Colowick SP, Kaplan NO (eds.): Methods Enzymol,.Vol. 105. Acad. Press, New York, Pp.422-429.

Carver,T.L.W., R.J. Zeyen, M.P. Robbins and G.A. Dearne. 1992. Effects of the PAL inhibitor, AOPP, on oat, barley and wheat cell responses to appropriate and inappropriate formae speciales of Erysiphe graminis DC. Physiol. Mol. Plant Pathol., 41: 397-409.

Chen, X., A. S. Marcelo, Y. Guiping, S. Jun and J. Dubcovsky. 2003. Development of Sequence Tagged Site and Cleaved Amplified Polymorphic Sequence Markers for Wheat Stripe Rust Resistance Gene Yr5. Crop Sci. 43: 2058-2064.

Dangl, J. L. and J. D. G. Jones. 2001. Plant pathogens and integrated defense responses to infection. Nature, 411:826-833.

El-Zahaby, H. M., G. Gullner and Z. Király. 1995. Effects of powdery mildew infection of barley on the ascorbate-glutathione cycle and other antioxidants in different host-pathogen interactions. Phytopathol., 85: 1225-1230.

Fabro, G., J. Steinbrenner, M. Coates, N. Ishaque, L. Baxter, et al., 2011. Multiple candidate effectors from the oomycete pathogen Hyaloperonospora arabidopsidis suppress host plant immunity. PLoS Pathog. 7, e1002348. doi:10.1371/journal.ppat.1002348.

Gechev, T., I. Gadjev, F. Van Breusegem, D. Inzé, S. Dukiandjiev, V. Toneva and I. Minkov. 2002. Hydrogen peroxide protects tobacco from oxidative stress by inducing a set of antioxidant enzymes. Cell Mol. Life Sci., 59:708714.

Hafez, Y. M. and Z. Király. 2003. Role of hydrogen peroxide in symptom expression of barley susceptible and resistant to powdery mildew. Acta Phytopathol., Entomol., Hung., 38: 227-236.

Hafez, Y.M., Fodor, J. and Király, Z. 2004. Establishment of systemic acquired resistance confers reduced levels of superoxide and hydrogen peroxide in TMV-infected tobacco leaves. Acta Phytopath. Entomol. Hung., 39: 347359.

Hafez, Y. M., A. Künstler and L. Király. 2007. Early accumulation of superoxide $\left(\mathrm{O}_{2}{ }^{-}\right)$in infected plants exhibiting non-host resistance. $11^{\text {th }}$ Congress of Phytopathology, Giza, Egypt, pp. 283-287.

Hafez, Y. M. 2009. Induction of systemic acquired resistance against tobacco mosaic virus by local inoculation and benzothiadiazole. Egypt. J. of Plant Pathol., 37 (2): 1-19.

Hafez, Y. M. 2010. Control of Botrytis cinerea by the resistance riducers benzothiadiazole $(\mathrm{BTH})$ and hydrogen peroxide on white pepper fruits under postharvest storage. Acta Phytopathol. Entomol. Hung., 45 (1): 1329.

Hafez, Y. M., R. Bacsó, Z. Király, A. Künstler and L. Király .2012. Up-regulation of antioxidants in tobacco by low concentrations of $\mathrm{H}_{2} \mathrm{O}_{2}$ suppresses necrotic disease symptoms. Phytopathol., 102: 848-856. 
Hafez, Y. M., Kh. A. A Abdelaal, N. A. El-Baghdady and A. F. Omar. 2011. Role of reactive oxygen species (ROS) in non-host resistance against phytopathogens. Egypt. J. Phytopathol., (39) 1: 180-186.

Hafez, Y.M., R.Y. Mourad, M. Mansour and Kh.A.A. Abdelaal. 2014. Impact of non-traditional compounds and fungicides on physiological and biochemical characters of barely infected with Blumeria graminis f.sp. hordei under field condtition. Egyptian J. Biol. Pest Cont., 24 (2): 445-453.

Hagborg, W. A. F. 1970. A device for injecting solutions and suspensions into thin leaves of plants. Can. J. Bot., 48: 1135-1136.

Harrach, B. D, J. Fodor, M. Pogány, J. Preuss and B. Barna. 2008. Antioxidant, ethylene and membrane leakage responses to powdery mildew infection of near-isogenic barley lines with various types of resistance. Eur. J. Plant Pathol., 121: 21-33.

Halliwell, B. and J. M. C. Gutteridge. 1999. Free Radicals in Biology and Medicine. Oxford University Press, Inc., New York.

Hammerschmidt, R., E.M. Nuckles and J. Kuć. 1982. Association of enhanced peroxidase activity with induced systemic resistance of cucumber to Colletotrichum lagenarium. Physiol. Plant Pathol., 20(1):73-82.

Heath, M. C. 2000. Nonhost resistance and nonspecific plant defenses. Curr. Opin. Plant Biol., 3: 315-319.

Horsfall, J. G. and E. B. Cowling. 1978. Pathometr: the measurement of plant disease. In: Horsfall, J.G. and E.B. Cowling, (Eds), Plant Disease: An Advanced Treatise. New York: Academic, Vol. II, pp. 120-136.

Hückelhoven, R., J. Fodor, C. Preis and K-H. Kogel. 1999. Hypersensitive cell death and papilla formation in barley attacked by the powdery mildew fungus are associated with $\mathrm{H}_{2} \mathrm{O}_{2}$ but not with salicylic acid accumulation. Plant Physiol., 119: 1251-1260.

Hückelhoven, R., C. Dechert and K-H. Kogel. 2001. Non-host resistance of barley is associated with a hydrogen peroxide burst at sites of attempted penetration by wheat powdery mildew fungus. Mol. Plant Pathol., 2: 199205.

Kim, H.S., G.L. Hartman, J.B. Manandhar, G.L. Graef, J.R. Steadman and B.W. Dier. 2000. Reaction of soybean cultivars to Sclerotia stem rots in field, greenhouse and laboratory evaluations. Crop Sci., 40: 665-669.

Király, L., B. Barna. and Z. Király. 2007. Plant resistance to pathogen infection: Forms and mechanisms of innate and acquired resistance. J. Phytopathol., 155: 385-396.

Király, L., A. Künstler, R. Bacsó, Y. M. Hafez and Z. Király. 2013. Similarities and Differences in Plant and Animal Immune Systems -What is Inhibiting Pathogens? Acta Phytopathol. Entomol. Hung., 45 (1): 13-29.

Klapheck, S., I. Zimmer and H. Cosse. 1990. Scavenging of hydrogen peroxide in the endosperm of Ricinus communis by ascorbate peroxidase. Plant Cell Physiol., 31: 1005-1013.

Levine, A., R. Tenhaken, R. Dixon and C. Lamb. 1994. $\mathrm{H}_{2} \mathrm{O}_{2}$ from the oxidative burst orchestrates the plant hypersensitive disease resistance response. Cell 79:583-593. 
Lipka, U., R. Fuchs, C. Kuhns, E. Petutschnig and V. Lipka. 2010. Live and let die-Arabidopsis nonhost resistance to powdery mildews. Eur. J. Cell Biol., 89:194-199.

O'Mahony, M. 1986. Sensory Evaluation of Food: Statistical Methods and Procedures. CRC Press, p. 487.

Schulze-Lefert, P. and R. Panstruga. 2003. Establishment of biotrophy by parasitic fungi and reprogramming of host cells for disease resistance. Annu. Rev. Phytopathol., 41: 641-67.

Schulze-Lefert, P. and S. Bieri. 2005. Recognition at a distance. Science, 308:506-508.

Thordal-Christensen, H. 2003. Fresh insights into processes of nonhost resistance. Curr. Opin. Plant Biol., 6: 351-357.

Trujillo, M.; M. Tröger; R.E. Niks; K-H. Kogel and R. Hückelhoven. 2004. Mechanistic and genetic overlap of barley host and non-host resistance to Blumeria graminis. Mol. Plant Pathol., 5: 389-96.

Watt, B.K. and A.L. Merrill. 1963. Composition of foods .U.S. Department of Agriculture, Agricultural Research Service, USDA .Hand Book. 8: 190.

Wu, G. S., B. J. Shortt, E. B. Lawrence, J. León, K. C. Fitzsimmons, E. B. Levine, I. Raskin and D. M. Shah. 1997. Activation of host defense mechanisms by elevated production of $\mathrm{H}_{2} \mathrm{O}_{2}$ in transgenic plants. Plant Physiol. 115:427-435.

Yulin, C., Z. Hongchang, Y. Juanni, W. Xiaojie, X. Jinrong, $H$. Qingmei, W. Guorong, H. Lili and K. Zhensheng. 2012. Characterization of non-host resistance in broad bean to the wheat stripe rust pathogen. BMC Plant Biology, 12:96 doi:10.1186/1471-2229-12-96. 


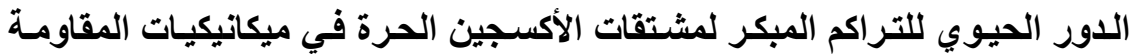

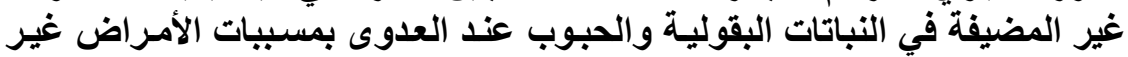
المتوافقة

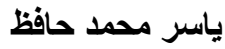
قُّم النبات الزراعي (فرع أمراض النبات)- كلية الزراعة - جامعة كفرالثيخ

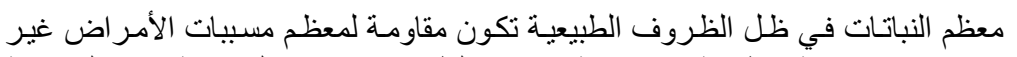

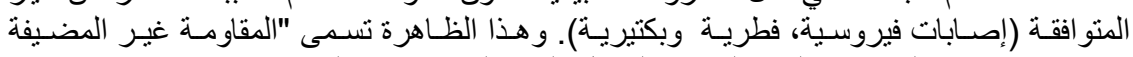
(NHR)

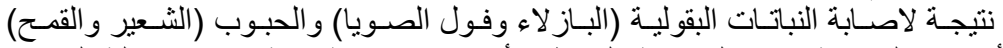

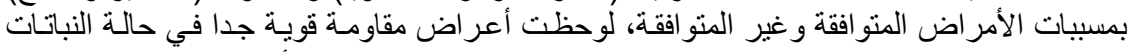

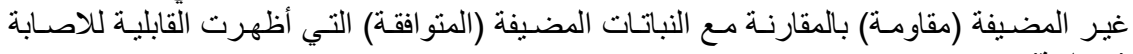

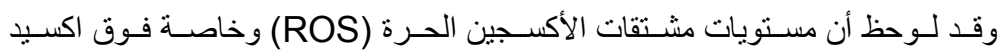
(حساسة)

الهيدروجين

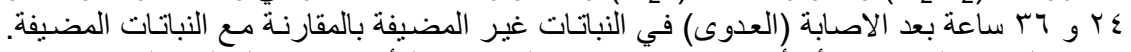

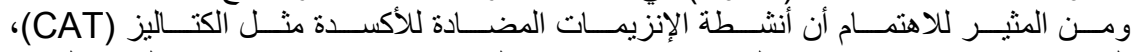

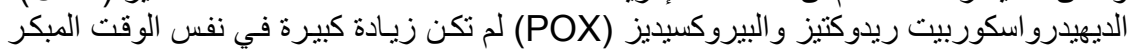

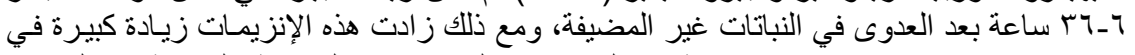

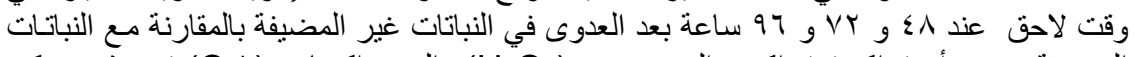

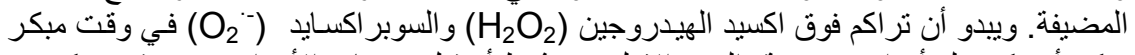

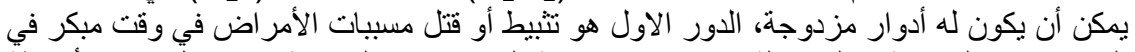

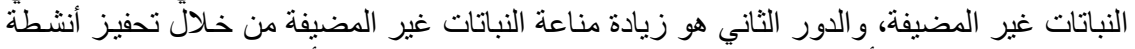

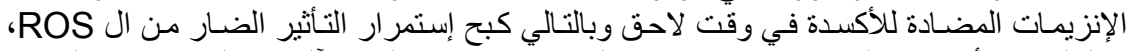

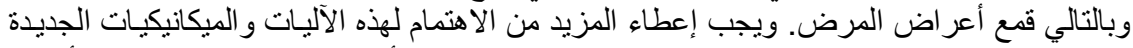

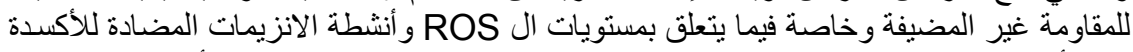
حيث أنها مهمة جدا لمربي النباتات ومفيدة للوصول لإستر اتيجيات المكافحة البديلة أيضا. 